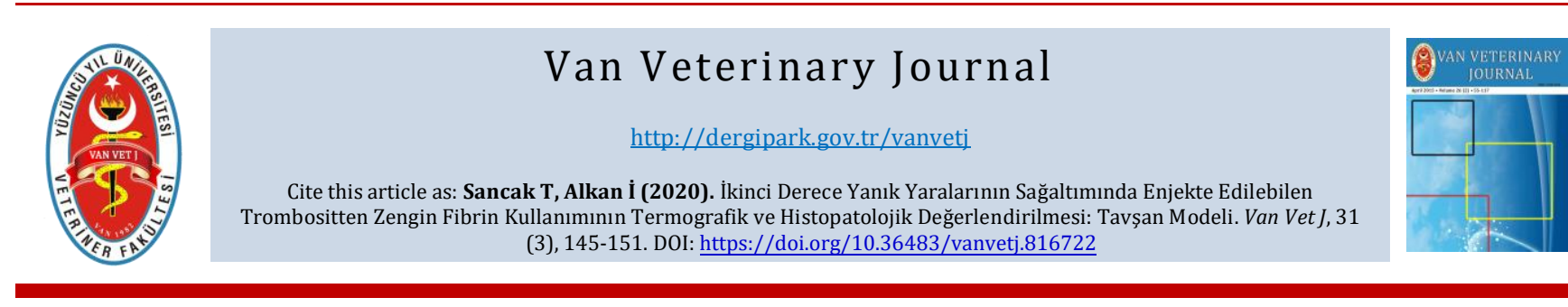

\title{
Thermographic and Histopathological Evaluation of Injectable Platelet Rich Fibrin On Treatment Of Second Degree Burn Wounds: Rabbit Model
}

\author{
Tunahan SANCAK ${ }^{*}$ İsmail ALKAN@ \\ Van Yuzuncu Yil University, Faculty of Veterinary Medicine, Department of Surgery, Van, Turkey \\ Received: 26.10 .2020 \\ Accepted: 04.11.2020
}

\begin{abstract}
In this study, it was aimed to evaluate the contribution of injectable platelet rich fibrin (i-PRF) to the healing of burn wounds using histopathological and thermographic data. For this purpose, 36 New Zealand rabbits were divided into two groups as the study and the control. After the burns were formed in rabbits in the study group, i-PRF was administered on $1^{\text {st }}, 3^{\text {rd }}$ and $7^{\text {th }}$ days. In the control group, $0.9 \%$ isotonic solution was administered on the same day. After burning, the temperature of burn area was measured with infrared thermal camera on 1 st, $2^{\text {nd }}, 3^{\text {rd }}, 7^{\text {th }}, 14^{\text {th }}$ and $21^{\text {st }}$ days. Randomly 6 rabbits were selected from both the study group and the control group. These rabbits were sacrificed on days 7, 14 and 21 and specimens were taken for histopathological examination from the burn area. In the examinations, it was observed that i-PRF increased cellular activity and accordingly, statistically significant temperature differences occurred between the burned area and normal skin on the $7^{\text {th }}, 14^{\text {th }}$ and $21^{\text {st }}$ days in the study group compared to the control group $(\mathrm{p}<0,05)$. The results of this research showed that i-PRF accelerates epithelization and collegenization in burn wounds. It is thought that many studies are needed in order to better understand the effect of $\mathrm{i}$-PRF on wound healing.
\end{abstract}

Keywords: Burn, i-PRF, Thermography, Treatment, Wound

öz

\section{İkinci Derece Yanık Yaralarının Sağaltımında Enjekte Edilebilen Trombositten Zengin Fibrin Kullanımının Termografik ve Histopatolojik Değerlendirilmesi: Tavşan Modeli}

Bu çalıșmada, enjekte edilebilen trombositten zengin fibrinin (E-TZF) yanık yaralarının iyileșmesine katkısının histopatolojik ve termografik veriler kullanılarak değerlendirilmesi amaçlanmıştır. Bu amaçla ikinci derece yanık yarası oluşturulan 36 adet Yeni Zellanda tavşanı çalışma ve kontrol olmak üzere iki gruba ayrılmıştır. Çalıșma grubundaki tavşanlara yanık olușturulduktan sonra E-TZF 1., 3. ve 7. gün uygulanırken, kontrol grubundaki tavşanlara \%0,9'luk izotonik solüsyonu aynı günlerde uygulanmıştır. Yanık oluşturulduktan sonra yanık bölgesinin sıcaklığı 1., 2., 3., 7., 14. ve 21. günlerde infrared termal kamerayla ölçülmüştür. Çalıșma ve kontrol grubundan rastgele seçilen 6'şar tavşan 7., 14. ve 21. günlerde sakrifiye edilerek yanık bölgesinden histopatolojik inceleme için örnekler alınmıştır. Yapılan incelemelerde E-TZF'nin hücresel aktiviteyi artırdığı ve buna bağlı olarak çalışma grubunda yanık bölgesiyle normal deri arasında 7., 14. ve 21. günlerde kontrol grubuna göre istatistiksel olarak anlamlı sıcaklık farklılıkları oluştuğu gözlemlenmiştir $(\mathrm{p}<0,05)$. Bu araştırmanın sonuçları E-TZF'nin yanık yaralarında epitelizasyonu ve kollejenizasyonu hızlandırdığını göstermektedir. E-TZF’nin yara iyileşmesi üzerine etkisini daha iyi anlayabilmek için çok sayıda araştırmaya ihtiyaç olduğu düşünülmektedir.

Anahtar Kelimeler: E-TZF, Sağaltım, Termografi, Yanık, Yara

\section{GíRiș}

Yara, canlı dokunun anatomik ve fonksiyonel bütünlüğünün bozulması olarak tanımlanmaktadır (Özkorkmaz ve Özay 2009). Yaralardaki iyileşme, sadece yara bölgesiyle sınırlı kalmaz. Bu süreç bütün sistemleri içeren hücresel, fizyolojik ve biyokimyasal olaylar bütünüdür (Gurtner ve Wong 2007; Parsak ve ark. 2007). Isı, kimyasal maddeler, elektrik ve radyoaktif ışınlar ile oluşan doku hasarına yanık denir (Aksoy 2015). Yanık; hasarın deri-derialtı dokularda oluştuğu, fakat derinliği ve yüzey alanı, yanığı oluşturan sebeplere bağlı olarak tüm vücudu etkileyen fizyopatolojik süreçtir (Özkaya ve ark. 2014). Yanık derinliğini tayin etmek için birçok yardımcı 
yöntem ve teknikten yararlanılabilir. Bunun için kullanılan teknik ve metodlar; klinik gözlem (ağrı, renk, bül), iyileşme süreci, biyopsi, floresan florometresi, vital boyalar (Metilen mavisi), lazer doppler flowmetri, termografi, nükleer magnetik rezonans görüntüleme ve kızılötesi ışın şeklinde sıralanabilir (Çetinkale 1997).

Yara iyileşmesini hızlandırmak için yapılan araştırmalar, uygun şartlarda hazırlanan, normal miktarının 4-5 katı daha fazla trombosit konsantrasyonlu ve kırmızı kan hücreli bir ürün elde etmek gerektiğini göstermektedir. Bir canlıda normalde trombosit sayısı mililitrede 250.000 iken, trombositten zengin plazmada bu sayısı mililitrede 1.000.000'dur. Bu miktar terapötik düzeydir (Jameson 2007). Trombositler çok sayıda büyüme faktörü içeren ürünlerdir (Weibrich ve ark. 2001). Son yıllarda, ilk kez Choukran tarafından tanımlanan trombositten zengin fibrin (PRF) sıklıkla kullanılmakta ve araştırılmaktadır. PRF'nin bildirilen avantajları arasında daha hızlı anjiyogenez, daha hızlı yara iyileşmesi, yüksek biyouyumluluk ve düşük maliyet bulunmaktadır. Bu biyolojik özelliklere ek olarak, i-PRF'nin antimikrobiyal, antiinflamatuvar ve antibiyofilm özelliklerine ilişkin umut verici çalıșmalar son zamanlarda literatürde dikkat çekmiştir (Aydınyurt ve ark. 2020).

Termografi, hastanın deri yüzeyindeki ısı örneklerini araştıran, kaydeden ve termogram adı verilen görüntüyü oluşturan tanısal bir görüntüleme yöntemidir (Düzgün ve Or 2009). İnfrared termografi, cilt yüzeyinden doğal olarak yayılan kızı̈ötesi radyasyonu kullanarak hastalıkların araştırılmasına olanak sağlar (Ring ve Ammer 2012). İnfrared termal görüntüleme ile veteriner hekimlikte; laminitis'lerin ve sırt ağrılarının teşhisi, tümörlerin erken tanısı, yumuşak doku hastalıkları ve damar lezyonlarının belirlenmesinin yanı sira topallıkların, Horner sendromunun, stres kirıklarının ve omurga yaralanmalarının tanısında, osteoartritislerin teşhisinde sinir hasarlarında tanıya yardımcı olması için kullanilmaktadır (Alan 2012).

$\mathrm{Bu}$ çalışmada; tavşanlarda oluşturulan 2. derece yanıklarda, lezyonlu alana enjekte edilebilen trombositten zengin fibrin (E-TZF) uygulamasiyla șekillenen yara iyileşmesinin histopatolojik ve termografik olarak incelenmesi amaçlanmıştır.

\section{MATERYAL ve METOT}

\section{Hayvan Materyali}

Araştırmanın materyal ve metodu Van Yüzüncü Yıl Üniversitesi Deney Hayvanları Yerel Etik Kurulu tarafından onaylanmıştır (Karar No: 2017/05). Çalıșmada ortalama 2-2,5 kg ağırlığında erkek 36 adet Yeni Zellanda tavşanı kullanıldı. Çalışmanın yürütüldügü tüm hayvanlara 1 haftalık adaptasyon dönemi sağlandı. Yanık oluşturma ve histopatolojik inceleme için örnek alma aşamalarından önce tavşanlar $5 \mathrm{mg} / \mathrm{kg}$ Xylasine hidroklorür (Rompun, Bayer HealthCare LLC, Germany) ve $50 \mathrm{mg} / \mathrm{kg}$ Ketamine hidroklorür'le (Alfamine, Egevet, İzmir, Türkiye) genel anesteziye alınd.

\section{Yanık Oluşturma}

Denemelerden önce bölgenin traş ve dezenfeksiyonu yapıldı. Denekler genel anesteziye alındı. Bütün hayvanların lumbosakral bölgesinde dorsomedian hatta yaklaşık $2 \times 5 \mathrm{~cm}$ alanında genel anestezi altında 2 . derece yanık yarası oluşturuldu. Yanıklar, $100^{\circ} \mathrm{C}$ 'de kaynayan suda 5 dakika boyunca bekletilen pirinç bar (yaklaşık 211 gr ağırlığında, $2 \times 5 \mathrm{~cm}$ taban yüzeyine sahip) ile yanık oluşturulacak bölgeye 15 sn boyunca pirinç barların ağırlığı dışında herhangi bir baskı yapılmadan oluşturuldu (Arslan ve ark. 2012). Yanık oluşturulduktan sonra bütün hayvanlara intraperitonal olarak hayvanın cüssesine göre 3-4 ml/kg olarak (8-10 cc) laktatlı ringer solüsyonu verildi.

\section{Enjekte Edilebilen Trombositten Zengin Fibrinin Hazırlanması}

Her deney hayvanından $9 \mathrm{ml}$ kan alındı ve E-TZF tüplerine aktarıldı. Kanlar santrifüj cihazına yerleștirildi ve 2 dakika süreyle 3300 rpm'de işleme tabi tutuldu (Mourão ve ark. 2015). Santrifüj gerçekleştirildikten sonra E-TZF çalışma grubundaki tavşanlara yanık yarasına hem subkutan olarak hem de gazlı beze emdirilerek lezyon oluşturulan alana uygulandı.

\section{Hayvan Deneyleri}

Tavşanlar randomizer programına (Research Randomizer) göre çalışma ve kontrol olmak üzere 2 gruba ayrıldı.

1.Grup (Çalışma grubu): Yanık yarası oluşturulan tavşanlardan rastgele 18 tanesine E-TZF uyguland. ETZF'nin yaklaşık 1,5 cc'si lezyonlu alanın kenarlarından subkutan olarak postoperatif 1 . gün, 3 . gün ve 7 . gün uyguland. Geri kalan yaklaşı 1,5 cc ise gazlı beze emdirilerek enjeksiyonun ardından yara üzerine uygulandı ve steril yara örtüsüyle koruma altına alındı.

2.Grup (Kontrol grubu): Kontrol grubunu geri kalan 18 tavşan kontrol grubunu oluşturdu. Bu gruptaki tavşanlara yanık oluşturulduktan sonra subkutan \%0,9'luk serum fizyolojik ortalama 1,5 cc olarak postoperatif $1 ., 3$., ve 7 . günlerde uygulandı. Çalışma grubundakine benzer olarak gazlı beze 1,5 cc $\% 0,9^{\prime}$ luk serum fizyolojik emdirildi ve yara üzerine uygulandı ve steril yara örtüsüyle koruma altına alındı.

\section{Termografik İnceleme}

Yanık olușturulduktan sonra 1., 2., 3., 7., 14. ve 21. günlerde çalışma ve kontrol gruplarındaki tavşanların yara bölgeleri, herhangi bir işlem yapılmadan önce Flir E50 (FLIR® Systems) marka infrared termal kamerayla (ortam ISı klima ile $21^{\circ} \mathrm{C} \pm 2$ 'ye sabitlenip hava akımının tek yönlü olması sağlanarak) incelendi. Sıcaklık verileri kaydedildi. Alınan verilerden Flir Tools (FLIR® Systems) programıyla hem yanık oluşturulan bölgeden hem de simetriğindeki yanık oluşturulmayan bölgeden alınan sıcaklık verileri incelendi.

\section{Histopatolojik İnceleme}

Çalışma ve kontrol gruplarından 7. günde, 14. günde ve 21. günlerde rastgele seçilen 6'şar tavşan sakrifiye edildi ve gerekli doku örnekleri alındı. Örnekler, yara bölgesinden ve lezyonsuz çevre dokudan yaklaşık 0,5 cm kadar kalınlığı içerecek şekilde alındı ve patoloji laboratuvarına gönderildi. Laboratuvardaki rutin işlemlerden sonra bloklardan $4 \mu \mathrm{m}$ kalınlığında alınan kesitler HematoksilenEozin (H\&E) boyama tekniğine göre boyanarak işık mikroskobunda (Nikon 80i-DSRI2) incelendi.

\section{İstatistiksel Analiz}

Çalışmanın istatistiki verileri (lezyonlu bölge - simetriği sağlam deri bölgesi) Medyan, Ortalama, Standart Sapma, Minimum ve Maksimum değerler kapsamında değerlendirildi. Kategorik değişkenler için "Sayı" ve "Yüzde" ifadeleri kullanıldı. Yanık bölgesi - simetriği sağlam yanmamış deri bölgesinin sıcaklık ortalamaları karşılaştırmalı olarak Wilcoxon testine tabi tutuldu. Çalışma ve kontrol grupları; yanık yarası kriter alınarak, zamanlar arası farklılıkları göstermede Friedman testiyle incelendi. Diğer taraftan çalışma ve kontrol gruplarındaki yaraların karşılaştırılmasında Mann-Whitney U testi kullanıldı. Hesaplamalarda istatistik anlamlılık düzeyi $(\alpha)$ 
$\% 5$ olarak alındı ve hesaplamalar için SPSS (IBM SPSS for Windows, ver.24) istatistik paket programları kullanıldı.

\section{BULGULAR}

Bu tez çalışmasında 36 adet Yeni Zellanda tavşanı üzerinde 2. derece yanık yarası oluşturularak yara iyileşmesinde ETZF uygulamasının etkisi termografik ve histopatolojik veriler kullanılarak değerlendirildi. Yapılan çalışmada çalışma grubunda iyileșme kontrol grubuna göre daha hızlı (\%35) şekillendiği ve 21. günde yanık yarası bölgesi makroskobik olarak incelendiğinde çalışma grubunda yara bölgesi kıllarla kapatılıp yara izi kalmazken, kontrol grubunda yara izinin kaldığı ve kıllarla kapatılamadığ belirlendi.

\section{Termografik Bulgular}

Yanık yarası ile normal deri sıcaklığının farkının değerlendirilmesinde "Sıcaklık farkı $\left({ }^{\circ} \mathrm{C}\right)=$ yanık yarası - normal deri sıcaklığı" formülü uygulandı. Hem çalıșma ve hem kontrol grubunda, 1., 2., 3., 7., 14., ve 21. günlerde yanık deri ve normal deri sıcaklıkları açısından istatistiksel olarak anlamlı farklılık bulunduğu tespit edildi $(\mathrm{p}<0.05$; Tablo 1). Her iki grupta da tavşanların yanık bölgesindeki sıcaklığının tüm günler arası değerlendirilmesinde istatistiksel olarak anlamlı fark olduğu gözlemlendi ( $\mathrm{p}<0.05$, Tablo 2).

Kontrol grubundaki tavşanlar ile çalışma grubundaki tavșanlarda olușturulan yanık bölgesinin termal kamera ölçümlerinin birbirlerine göre karşılaştırılmasında ise 1. ve 2. günlerde anlamlı bir fark oluşmazken ( $p>0.05$, Tablo 3 ), diğer günlerdeki (3., 7., 14. ve 21. günler) ölçümlerde istatistiksel olarak anlamlı bir fark olduğu gözlenmiștir $(\mathrm{p}<0.05$, Tablo 3).

Tablo 1. Kontrol ve çalıșma grubunda yanık yarası ile normal deri sıcaklık ölçümlerinin karşılaștırma sonuçları (Wilcoxon testi).

Table 1. Comparison results of burn wound and normal skin temperature measurements in control and study groups (Wilcoxon test).

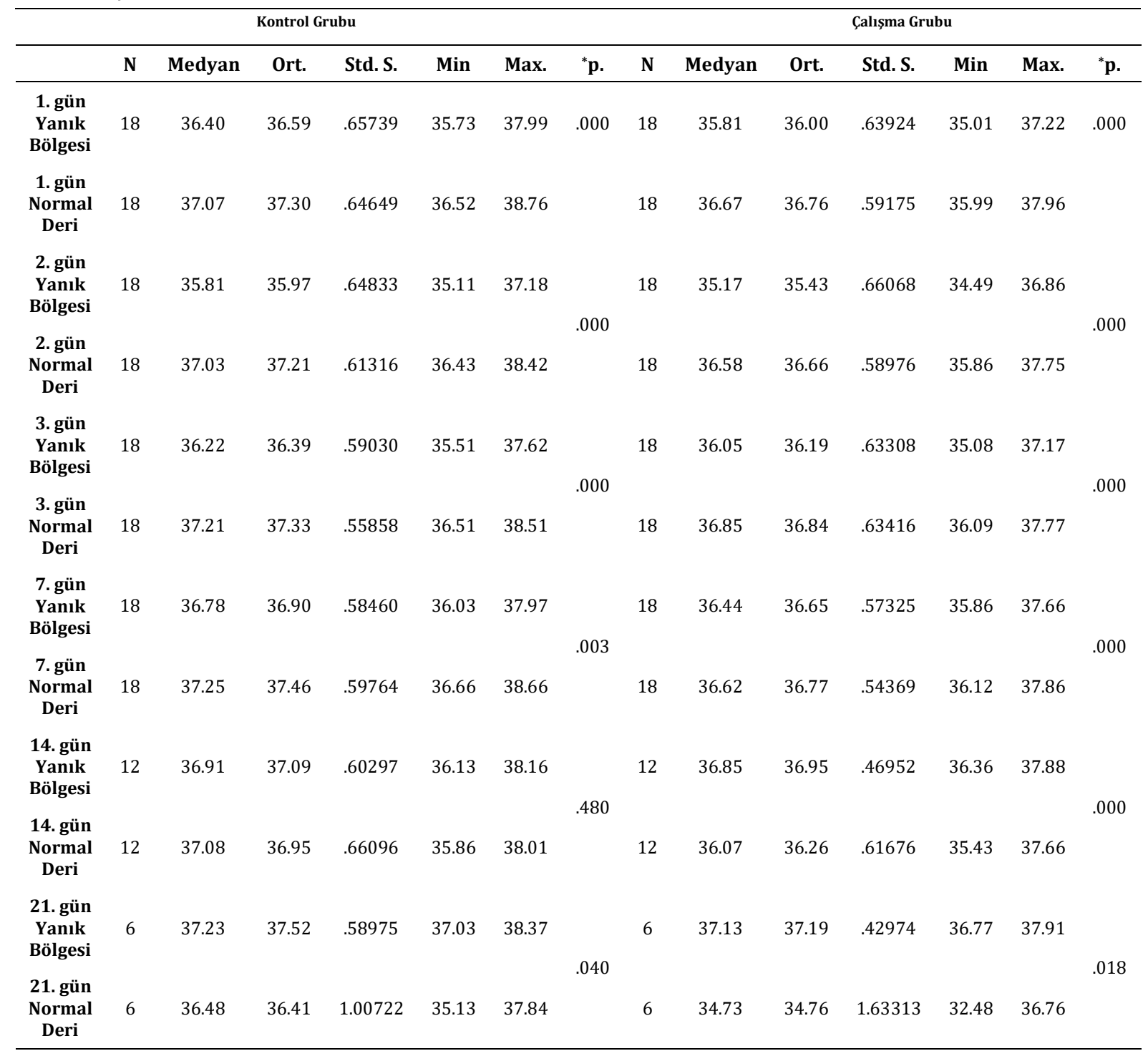

${ }^{*} \mathrm{p}<0.05$ : istatistiksel olarak anlamlı fark vardır. 
Tablo 2. Kontrol ve çalışma grubunun günler arası sıcaklık ölçümü karşılaştırma sonuçları (Friedman Testi).

Table 2. Comparison results of the control and study group between days temperature measurement (Friedman Test).

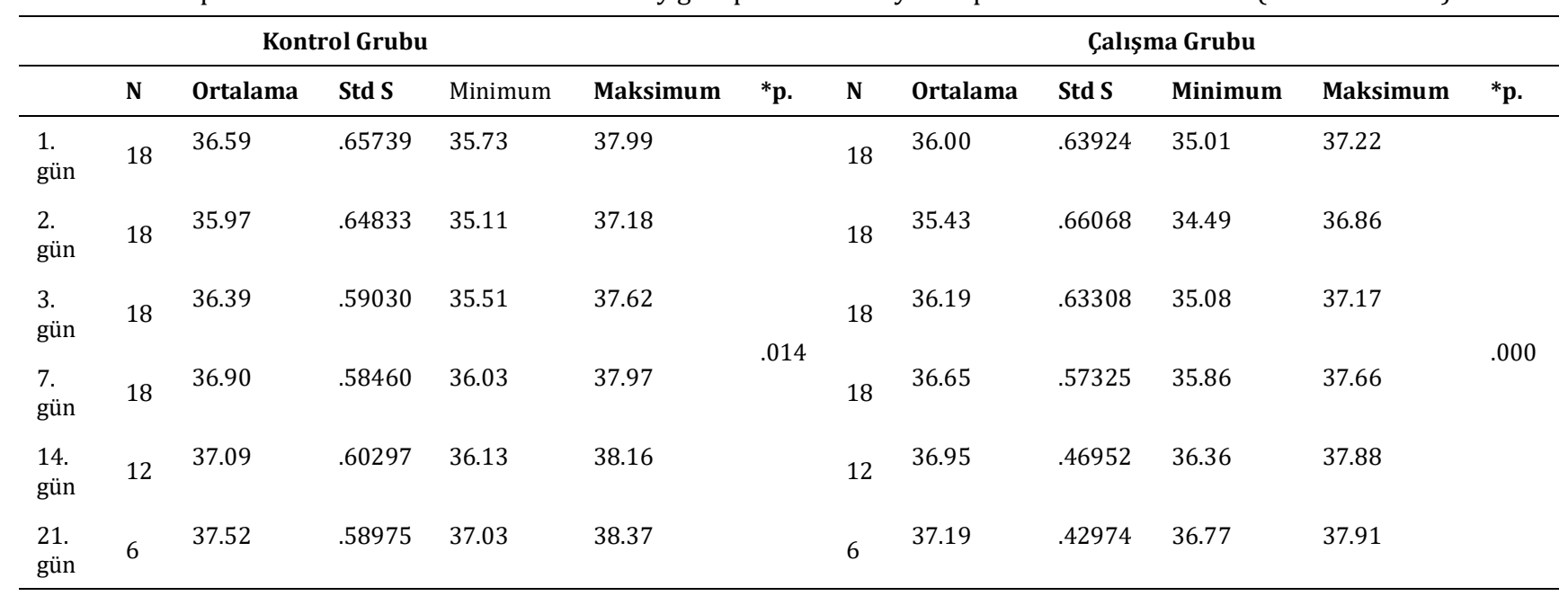

${ }^{*} \mathrm{p}<0.05$ : istatistiksel olarak anlamlı fark vardır.

Tablo 3. Yanık bölgesi sıcaklık ölçümlerinin gruplara göre karşılaştırma sonuçları (Mann-Whitney U Testi).

Table 3. Comparison results of burn zone temperature measurements by groups (Mann-Whitney U Test).

\begin{tabular}{|c|c|c|c|c|c|c|c|c|c|c|c|c|c|}
\hline \multirow[b]{2}{*}{ Gün } & \multicolumn{6}{|c|}{ Kontrol Grubu } & \multicolumn{6}{|c|}{ Çalışma Grubu } & \multirow{2}{*}{${ }^{*}$ p. } \\
\hline & $\mathbf{N}$ & Medyan & Std. S. & Ort. & Min. & Maks. & $\mathbf{N}$ & Medyan & Std. S. & Ort. & Min. & Maks. & \\
\hline 1. & 18 & 36.40 & .657 & 36.59 & 35.73 & 37.99 & 18 & 35.81 & .639 & 36.00 & 35.01 & 37.22 & .058 \\
\hline 2. & 18 & 35.81 & .648 & 35.97 & 35.11 & 37.18 & 18 & 35.17 & .660 & 35.43 & 34.49 & 36.86 & .060 \\
\hline 3. & 18 & 36.22 & .590 & 36.39 & 35.51 & 37.62 & 18 & 36.05 & .633 & 36.19 & 35.08 & 37.17 & .049 \\
\hline 7. & 18 & 36.78 & .584 & 36.90 & 36.03 & 37.97 & 18 & 36.44 & .573 & 36.65 & 35.86 & 37.66 & .042 \\
\hline 14. & 12 & 36.91 & .602 & 37.09 & 36.13 & 38.16 & 12 & 36.85 & .469 & 36.95 & 36.36 & 37.88 & .041 \\
\hline 21. & 6 & 37.23 & .589 & 37.52 & 37.03 & 38.37 & 6 & 37.13 & .429 & 37.19 & 36.77 & 37.91 & .034 \\
\hline
\end{tabular}

${ }^{*} \mathrm{p}<0.05$ : istatistiksel olarak anlamlı fark vardır.

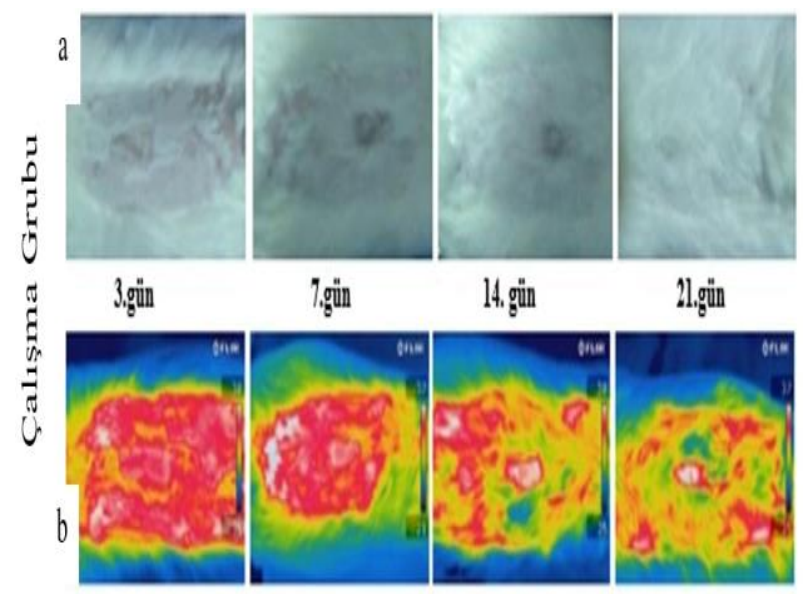

Şekil 1. Çalışma grubunun 3., 7., 14. ve 21. gün termal ve normal deri görüntüleri

Figure 1. Thermal images of the study group on the 3rd, 7 th, 14 th and 21 st days.

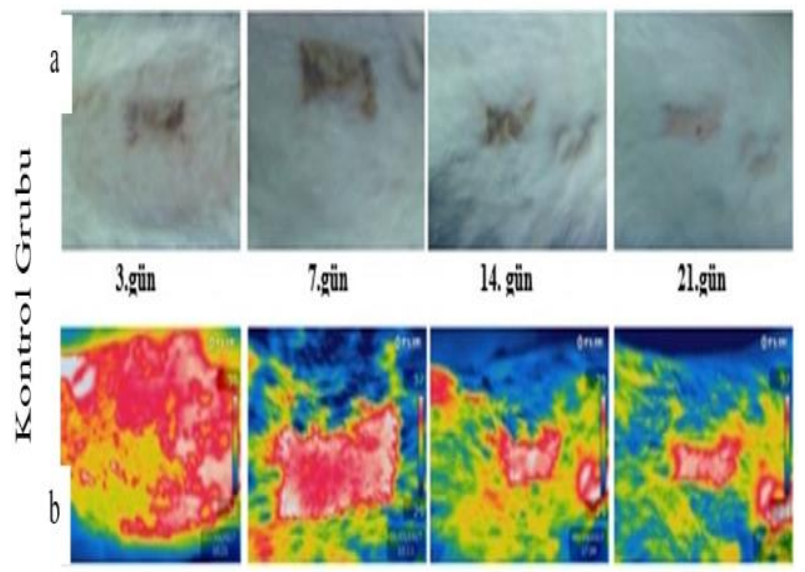

Şekil 2. Kontrol grubunun 3., 7., 14 ve 21. gün termal ve normal deri görüntüleri

Figure 2. Thermal images of the control group on the 3rd, 7 th, 14 th and 21 st days. 


\section{Histopatolojik Bulgular}

\section{Gün Bulguları}

Kontrol grubunda yanık bölgesinde (I) işaretiyle gösterilen yerde yanık kenarlarında da dahil olmak üzere epidermiste rejenerasyon gözlenmezken, çalışma grubunda siyah oklarla gösterilen yerde yanık bölgesinin her iki uçtaki kenarlarından başlayarak nekrotik alan altında ilerleyen kısmi epidermal rejenerasyon dikkati çekmektedir. Kontrol grubunda dermiste nekroz alanları, çoğunluğunu eozinofil lökositlerin oluşturduğu lökositlerle kuşatılmış olarak görünürken (İnflamasyon evresi); çalışma grubunda nekrotik kıl follikülleri ve ter bezlerinin hayali sınırları ile, dejeneratif-nekrotik bölgelerin hemen altındaki dermiste eozinofil lökosit infiltrasyonu ve ödem saptanmıştır (İnflamasyon - Proliferasyon Evresi) (Şekil $3)$.

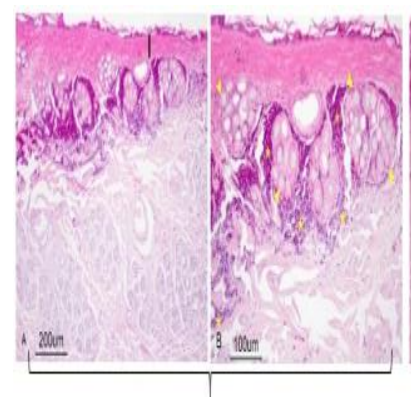

Kontrol Grobu

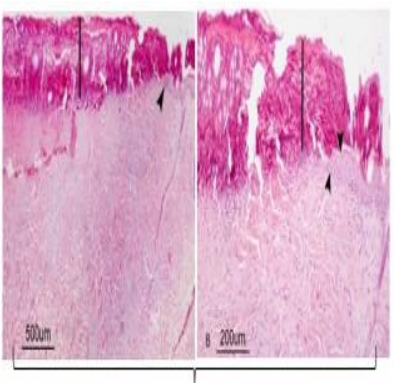

Calsma Grobu
Şekil 3. Kontrol ve çalışma grubu 7. gün H\&E.

Figure 3. Control and study group 7th day H\&E.

\section{4. gün bulguları}

Kontrol grubunda yanık bölgelerinde ok başlarıyla gösterilen yerlerde yanık kenarlarından başlayan epidermisteki rejenerasyonun orta bölgeye doğru ilerlediği ve orta bölgede oklarla gösterilen alanlarda henüz rejenerasyon oluşmadığı ayrıca nekrotik bir kitle ile örtülü olduğu görülürken (İnflamasyon- Proliferasyon Evresi); çalıșma grubunda yanık kenarlarından bașlayan epidermisteki rejenerasyonun tamamlandığ epidermal rejenerasyon henüz düzleşmediği ve konkav görünüme sahip olduğu görüldü (oklarla gösterilen alan). Aynı zamanda çalışma grubunda dermiste de anjiyogenezis ve lökositlerden fakir fibroblast proliferasyonu gözlendi. Yıldız ile gösterilen alanlarda dermisteki reaksiyon bu görünümüyle gevșek bir bağ doku proliferasyonu şeklindedir (Proliferasyon-Remodeling Evresi) (Şekil 4).

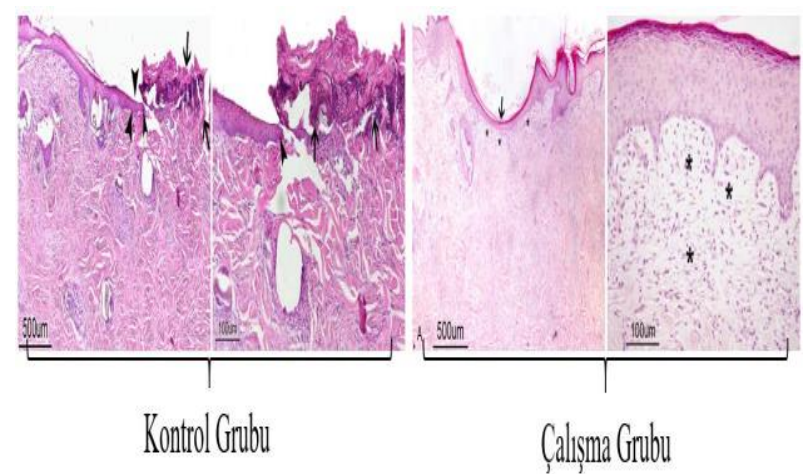

Şekil 4. Kontrol ve çalışma grubu 14. gün H\&E.

Figure 4. Control and study group 14th day H\&E.

\section{1. gün bulguları}

Kontrol grubunda yanık bölgesinde oklarla gösterilen alanlarda, yanık kenarlarından başlayan epidermisteki rejenerasyonun tamamlandığı, ancak rejenere epidermisin henüz iç konkav görünümde olduğu ve epitel katının gelişmesinin de yetersiz olduğu görülürken, ok başları ile belirtilen alanlarda dermiste kısmen gevșek bir bağ doku proliferasyonu gözlenmektedir (Proliferasyon-Remodeling Evresi); bunun yanında çalışma grubunda yanık bölgesinde oklarla gösterilen alanlarda, epidermisteki rejenerasyonun tamamlandığı ve çoğunlukla düzleştiği, epitel katının da oldukça kalın olduğu, hatta dermise doğru da papiller uzantılar oluşturduğu görülmektedir. Ayrıca rejenere epidermal katta stratum corneum (1), stratum spinosum (2) ve stratum basale (3) tabakalarının belirgin bir şekilde oluştuğu ve yıldızla gösterilen alanlarda ise dermiste daha sıkı bir bağ doku proliferasyonu gözlenmektedir (Remodeling) (Şekil 5).
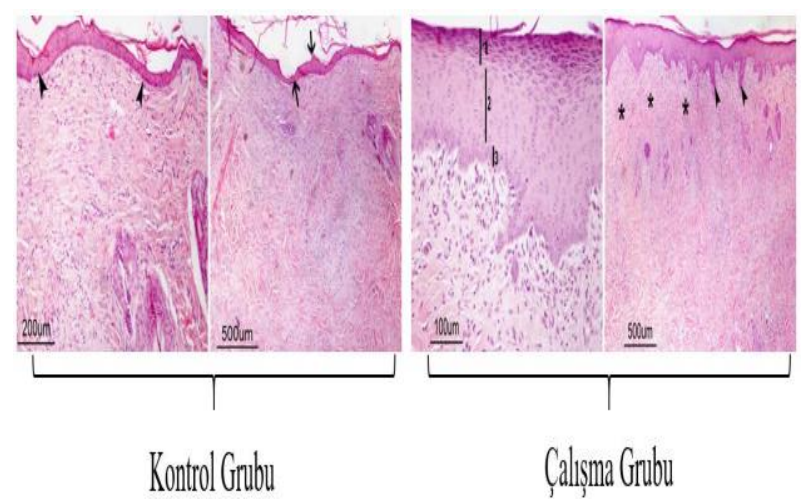

Şekil 5. Kontrol ve çalışma grubu 21. gün H\&E.

Figure 5. Control and study group 21st day H\&E.

$\mathrm{Bu}$ çalışmada, çalışma grubu ile kontrol grubu histopatolojik olarak karşılaştırıldığında; çalışma grubunda epitelizasyonun, kontrol grubuna göre daha erken başladı̆̆ı ve daha erken tamamlandı̆̆ı, ayrıca kollejenizasyonun da daha güçlü şekillendiği saptandı.

\section{TARTIŞMA ve SONUÇ}

Kızılötesi termografi, normal ve lezyonlu derideki kan akışı değişikliklerini saptamada yaygın olarak kullanılmaktadır. Yanık yarası oluştuktan sonraki 3 gün içinde yanık derinliğini tahmin etmede termografi çok yararlıdır. Yanıklar değerlendirilirken, kızılötesi radyasyon algılanması yara yüzeyindeki kutanöz kan akışı ile ilişkilidir ve dolaylı olarak yanık derinliği hakkında bilgi verir. Deri kan damarlarında ortaya çıkan hasar, yüzeysel deri kan akışında bir azalma veya durmaya yol açar ve bu da yüzey sıcaklığının düşmesine neden olur. Derin yanık yaraları, yüzeysel olanlardan daha soğuktur. Yüzeysel yaralarda vasküler perfüzyon daha azdır. $\mathrm{Bu}$ nedenle, termografide ölçülen sıcaklık derinlikle ters yönde ilişkilendirilir (Cole ve ark. 1991; Liddington ve Shakespeare 1996; Monstrey ve ark. 2008). Hardwicke ve ark. (2013) tarafından yapılan çalışmada 2. derece yanık yarasında, ilk üç gün yapılan ölçümlerde 2. gündeki yanık bölgesi ile normal deri arasındaki ortalama sıcaklık farkı ortalama $-1.2{ }^{\circ} C^{\prime}$ dir. Yapılan bu çalışmada da, her iki grupta yanık yarası ile normal deri arasındaki sıcaklık farkı 2. gün sonrası yapılan ölçümlerde ortalama $-1.2{ }^{\circ} \mathrm{C}$ olarak tespit edilmiştir. Bu sıcaklık farkı lezyonda ikinci derece yanık yarası oluştuğunu göstermektedir $(\mathrm{p}<0.05$, Tablo 1 , Tablo 2). Bu veriler Hardwicke ve ark. (2013) tarafından yapılan çalışma bulgularıyla benzerlik göstermektedir. 
Ayrıca Renkielska ve ark. (2005) ile Renkielska ve ark. (2006)'nın gerçekleștirdiği çalıșmalarda, her grup içinde işlem sonrasındaki üç günde alınan ölçümlerin birbirleriyle olan karşılaștırmalarında istatistiki olarak anlamlı bir fark bulunamamıștır. Bu çalıșmada elde edilen bulgularda her iki grup için de ilk üç gündeki karşılaştırmalarda anlamlı bir fark bulunamamıștır ( $p>0.05$, Tablo 2). Sonuçların Renkielska ve ark. (2005) ve Renkielska ve ark. (2006)'nın çalışmalarıyla benzer olduğunun saptanması çalışmanın doğru planlandığının göstergesidir.

E-TZF, büyüme faktörlerinin (PDGF-AA, PDGF-AB, EGF ve IGF-1) lezyonlu alana göçünü hızlandırır. $\mathrm{Bu}$ büyüme faktörleri, uygulamadan 15 dakika sonra bölgeye hareket ederler. Bundan sonraki 10 günde giderek azalacak biçimde salınırlar (Fujioka-Kobayashi ve Miron 2017).

Yanık yarası oluşturulduktan sonra derideki kan damarları yıkımlanır, buna bağlı olarak yaralar daha soğuk görünür. Ancak 3 gün sonra sıcaklık artmaya bașlar. Bu ısınmanın nedeni, granülasyon dokusu şekillenmesi için ortaya çıkan vasküler gelișmeyle ilintilidir. Derin yanıklarda ise bu iyileşme yavaş şekillenmektedir (Liddington ve Shakespeare 1996). Bu çalışma sırasında elde edilen termografik bulgulara göre, yanık yarası ile normal deri arasındaki sıcaklık farkı çalışma grubunda işlemden sonraki 3. günden itibaren kontrol grubuna göre daha fazla azalmaya başladığı saptanmıştır. Bu bulgu E-TZF'nin etkilerine bağlı olarak hücresel aktivitenin çalışma grubunda, kontrol grubuna göre daha hızlı olduğunun bir kanıtıdır. Yedinci ve ondördüncü günde gerçekleștirilen histopatolojik bulgularda hücresel aktivitenin çalıșma grubunda daha fazla gerçekleștiğinin tespit edilmesi bu çalışmanın önemli sonuçlarıdır. Çalışma grubunda E-TZF uygulanan yanık yaralarının 7. günde normal deriyle aynı seviyelerde, 14. günde ise normal deriye göre daha sıcak olduğu tespit edilmiștir $(\mathrm{p}<0.05$, Tablo 2). Kontrol grubunda ise bu sicaklı farkl daha az miktarda şekillenmiştir. Liddington ve Shakespeare (1996) kısmi kalınlıktaki yanık yaralarında su geçirmez membran uygulaması yapmıș ve uygulamadıklarına göre 3. günden itibaren yanık yarası sıcaklığının daha fazla artmaya başladığını belirlemiştir. Bu çalışmada da E-TZF uygulanan yanıklardaki sıcaklık artışı uygulanmayanlara göre daha fazla șekillenmiștir. $\mathrm{Bu}$ bulgular Liddington ve Shakespeare (1996)'in bulgulariyla benzerlik göstermektedir.

Kılsız hayvanlarda yayılan kızılötesi radyasyon deri yüzey sıcaklığ yayılan radyasyon ya deri ya da kllar tarafindan tamamen engellenebilir. Kılların yüzeyinden yayılan sıcaklık farkı, deri ile kıl örtüsü yüzeyi arasındaki sıcaklık gradyanı aracılığıyla belirlenir. Kalın kürklü hayvanlarda, infrared termal kamera ile ölçülen yüzey sıcaklığı, kıl örtüsünün fiziksel yüzeyinin birkaç milimetre altındadır. Bir memelinin yüzey sıcaklığı yalnızca deri sıcaklığından etkilenmez, aynı zamanda bu etkilenmede vücudun farklı bölgelerindeki kılların kalınlığı, yoğunluğu ve kalitesi de rol oynar. Bu durum farklı türler arasında, mevsime bağlı deride gelișen yüzeysel dökülmeler ya da tüy dökme nedeniyle değişmektedir (McCafferty 2007). Bu çalışmanın 21. gününün her iki grup verileri yanık yarası ile normal deri arasında sıcaklık farkının çok daha fazla oranda olduğunu ortaya koymuştur ( $\mathrm{p}<0.05$, Tablo 1 , Tablo 2$)$. Bu bulgu tavşanların yara çevresindeki kıllarının uzamaya bașladığı döneme denk geldiği için kılların normal deri sıcaklığını daha düşük gösterdiği șeklinde yorumlanmıștır.
Yara iyilessmesinde dermal veya subdermal enjekte edilen konsantre trombositler veya onların büyüme faktörleri oldukça etkili otolog kollajen gelişimi sağlar. Otolog büyüme faktörleri ile fibroblast stimülasyonu dermiste ya da dermal-subdermal birleşme noktasında kollajen birikimini uyararak, sağaltımdan birkaç hafta sonra bile faydalı bir etki gösterir (Sclafani 2010). E-TZF'nin yapısında bulunan kan hücrelerinin çoğu lökositler (monositler, nötrofiller, lenfositler) ve trombositlerdir. Ayrıca bunların yanında dolaşımdaki kök hücreler ve endotel hücreleri de E-TZF'nin yapısında bulunmaktadır (Ciravegna 2016). Trombositten zengin fibrinin bir sonraki adımı olarak E-TZF, gelișmiş trombositten zengin fibrinin özelliklerini sıvı șekilde sunar. Ayrıca E-TZF kandan bir miktar da kök hücre yakalar. Çeşitli otolog büyüme faktörlerini içeren E-TZF, bunları sürekli ve yavaş serbest bırakır (Melek ve El Said 2017). E-TZF'nin diğer bir avantajı, enjeksiyon sonrası hemen pıtılaşarak bir biyomateryal olușturmasıdır. Ayrıca kovalent olmayan birleşme için herhangi bir biyomateryal ile kombine edilebilir (Masoudi ve ark. 2016).

Özçelik (2009)'in 2. derece yanık yarasında yaptığı çalışmada yara bölgesine enjekte ettiği trombositten zengin plazma sayesinde fibroblast aktivasyonunu ve kollejenizasyonu artırdığını savunmaktadır. Bu çalıșmada 1. gruptaki histopatolojik örneklere göre 14. günde fibroblast aktivasyonunun başladığı gözlenmiştir. 21. günde fibroblast aktivasyonuna bağlı olarak güçlü bir kollejenizasyonun şekillendiği ortaya konulmuştur. Ancak 14. gündeki kontrol grubu örnekleri incelendiğinde ise; fibroblast aktivetesinin bașlamadığı tespit edilmiștir. Bu bulgular Özçelik (2009)'in çalıșmasıyla benzerlik göstermekte ve yeni yapılacak çalıșmalar için oldukça kanıt verici olduğu düşünülmektedir.

Ayrıca Subrahmanyam (1998) 2. derece yanık yarası sağaltımı için bal kullandığını belirtmektedir. Çalıșmasının 7. gününde epitelizasyonun sağlandığı ve 21. günde tamamlandığı vurgulanmaktadır. Subrahmanyam'ın çalıșma bu çalıșmanın sonuçları epitelizasyon açısından birbirine benzerdir. Yüksel (2012)'in ratlarda 2. derece yanık oluşturarak gerçekleştirdiği çalışmada \%0,9' luk sodyum klorür, \%1' lik gümüș sülfadiazin ve $\% 10^{\prime}$ luk povidon iyot kullandığını belirtmektedir. Bu araştırmanın sonuçlarına göre; 7., 14., ve 21. günlerde epitelizasyon ve kollejenizasyon açısından grupların hiçbirinde birbirine göre fark oluşmadığı belirtilmiștir. Her üç grupta elde edilen 7. gün (yangı hücreleri artışı), 14. gün (kollejen artışı ve epitelizasyon başlangıcl) ve 21. gün (kollejenizasyon ve epitelizasyonun ilerlemesi) bulguları bu çalışmanın kontrol grubundaki verilerle benzerlik göstermektedir. Yapılan bu çalışmada, çalıșma grubunda tavşanlarda uygulanan E-TZF, ratlarda uygulanan \%1' lik gümüş sülfadiazin ve $\% 10$ 'luk povidon iyota kıyasla daha hızlı bir yara iyileșmesine katkı sağlamıștır.

Buz (2012)' un parsiyel kalınlıktaki yanık yaralarının (2. derece yanık) sağaltımı için gerçekleștirdiği çalıșmasında taurin, L-karnitin ve glutatyonu mezoterapik ajan olarak uyguladığını belirtmektedir. Böylelikle çalıșma grubunda uyguladığı mezoterapik ajanların kontrol grubuna göre epitelizasyon ve kollejenizasyonu artırdığı, ancak 22 . günde alınan örneklerin değerlendirilmesinde taurin, Lkarnitin ve glutatyonun kollejenizasyonu ve epitelizasyonu yüzeysel olarak șekillendirdiği belirtilmektedir. Buz (2012)' un ratlarda elde ettiği sonuçlar ile tavşanlardaki bu çalışmanın sonuçları karşılaştırıldığında E-TZF'nin; taurin, L-karnitin ve glutatyona göre yara iyileşmesinde kollejenizasyon ve epitelizasyonu önemli ölçüde artırdığını göstermektedir. 
$\mathrm{Bu}$ çalıșmada 7., 14. ve 21. günde alınan örneklerden yapılan histopatolojik incelemeler sirasinda; E-TZF uygulanan olgulardan alınan örneklerde epitelizasyonun kontrol grubuna göre daha önce bașladığı (inflamasyon evresinin tamamlandığı ve proliferasyon evresine geçildiği) (7. günde), devam ettiği (remodeling evresine geçtiği) ve 21. günde tamamlandığı (remodeling evresi) ortaya konulmuştur. Kontrol grubunda ise, epitelizasyonun yetersiz düzeyde olduğu (inflamasyon ve proliferasyon evrelerinin çalışma grubuna göre geç tamamlandığı, 21. günde remodeling evresinin ise henüz tamamlanmadığı) saptanmıştır. Bu şekilde E-TZF uygulanan yanık yaralarında yara iyileşme evrelerinin epitel onarımının daha hızlı șekillendiği belirgin bir șekilde gözlenmiștir.

Çalışmanın sonunda elde edilen bulgular ışığında; E-TZF yapısında herhangi bir katkı maddesi bulunmaması, kanının doğrudan santrifüjlenmesiyle elde edilen otolog, doğal bir ürün olarak uygulanabilirliğinin ortaya konması, düșük maliyetli olması, hazırlanması ve uygulanması diğer trombosit konsantrasyon yöntemlerine göre daha hızlı ve kolay olması ve en önemlisi yanık yaralarında epitelizasyonu ve kollejenizasyonu stimüle eden bir ürün olduğunun tespit edilmesi E-TZF'nin avantajları olarak sıralanabilir. E-TZF'nin bütün bu yararları göz önüne alındığında yumuşak doku lezyonlarında kolaylıkla uygulanabileceği ve sonuç olarak E-TZF'nin yanık yaralarında iyileșme sürecini hızlandırdığı kanaatine varılmıștır.

\section{ÇIKAR ÇATIŞMASI}

Yazarlar, çıkar çatışması olmadığını beyan eder.

\section{TEŞEKKÜR}

$\mathrm{Bu}$ araştırma Van Yüzüncü Yıl Üniversitesi Bilimsel Araştırma Projeleri Başkanlığı tarafından TDK-2016-5421 nolu proje ile desteklenmiștir.

\section{KAYNAKLAR}

Aksoy N (2015). Yanıklı hastada hemşirelik bakımının yönetimi. Selçuk Tıp Derg, 31, 47-51.

Alan A (2012). Termografi ve veteriner hekimliğinde kullanımı. Erciyes Üniv Vet Fak Derg, 9, 2, 133-140.

Arslan K, Karahan Ö, Okuş A et al. (2012). Yanık yarası tedavisinde topikal çinko oksit ile gümüş sülfadiazinin karşılaştırılması. Ulus Travma Derg, 18 (5), 376-383.

Aydınyurt HŞ, Sancak T, Taskin C, Başbuğan Y, Akıncı L (2020). Effects of injectable platelet-rich fibrin in experimental periodontitis in rats. Odontology, https://doi.org/10.1007/s10266-020-00557-1

Buz A (2012). Parsiyel Kalınlıkta Termal Yanıkların Tedavisinde Mezoterapinin Etkinliği- Deneysel Çalışma. Uzmanlık Tezi, Bülent Ecevit Üniversitesi Tıp Fakültesi, Zonguldak.

Ciravegna J (2016). Le PRF dans les techniques de chirurgie plastique parodontale: un réel bénéfice? Doktora Tezi, Nice.

Cole RP, Shakespeare PG, Chissell HG, Jones SG (1991). Thermographic assessment of burns using a nonpermeable membrane as wound covering. Burns, 17, 2, 117-122.
Çetinkale 0 (1997). Yanıklara ilk yaklaşım. İstanbul Üniversitesi Cerrahpașa Tıp Fakültesi Sürekli Tıp Eğitimi Etkinlikleri, Acil Hekimlik Sempozyumu, 255-268.

Düzgün D, Or ME (2009). Termal kameraların tıpta veteriner hekimlikte kullanımı. TÜBAV Bilim Derg, 4, 468-475.

Fujioka-Kobayashi M, Miron RJ (2017). Biological Components of Platelet Rich Fibrin: Growth Factor Release and Cellular Activity In: Platelet Rich Fibrin in Regenerative Dentistry: Biological Background and Clinical Indications, Miron RJ, Choukron J (Eds), John Wiley \& Sons Ltd, USA.

Gurtner GC, Wong VW (2007). Wound Healing: Normal And Abnormal. In: Grabb and Smith's Plastic Surgery, 6th Edition, Thorne CH, Beasley RW Aston SJ, Barlett SP, Gurtner GC, Spear SL (Eds), Lippincott-Williams and Wilkins, USA.

Hardwicke J, Thomson R, Bamford A, Moimen N (2013). A pilot evaluation study of high resolution digital thermal imaging in the assessment of burn depth. Burns, 39, 76-81.

Jameson CA (2007). Autologous platelet concentrate for the production of platelet gel. Labmedicine, 38 (1), 39-42.

Liddington MI, Shakespeare PG (1996). Timing of the thermographic assessment of burns. Burns, 22, 1, 26-28.

Masoudi EA, Ribas J, Kaushik G et al. (2016). Platelet-rich blood derivatives for stem cell-based tissue engineering and regeneration. Curr Stem Cell Rep, 2, 33-42.

McCafferty DJ (2007). The value of infrared thermography for research on mammals: previous applications and future directions. Mammal Rev 37, 3, 207-223.

Melek LN, El Said MM (2017). Evaluation of "Autogenous Bioengineered Injectable PRF - Tooth graft" combination (ABIT) in reconstruction of maxillary alveolar ridge defects: CBCT volumetric analysis. SJDR, 8, 8696.

Monstrey S, Hoeksema H, Verbelen J, Pirayesh A, Blondeel P (2008) Assessment of burn depth and burn wound healing potential. Burns, 34, 761-769.

Mourão CF, Valiense H, Melo ER, Mourão NB, Maia MD (2015). Obtention of injectable platelets rich-fibrin (i-PRF) and its polymerization with bone graft: technical note. Rev Col Bras Cir, 42, 421-423.

Özçelik Ü (2009). Kısmi Kalınlıkta Yanık Sonrası Trombosit Zengin Plazmanın Lokal Uygulanmasının Yara İyileșmesi Üzerine Etkileri. Uzmanlık Tezi, Başkent Üniversitesi Tıp Fakültesi, Ankara.

Özkaya NK, Alğan S, Akkaya H (2014). Yanıklı Hastanın Değerlendirilmesi ve Tedavi Yaklaşımının Belirlenmesi. Ankara Med J, 14 (4), 170-175.

Özkorkmaz EG, Özay Y (2009). Yara iyileșmesi ve yara iyileșmesinde kullanılan bazı bitkiler. Türk Bilimsel Derlemeler Dergisi, 2 (2), 63-67.

Parsak CK, Sakman G, Çelik Ü (2007). Yara iyileșmesi, yara bakımı ve komplikasyonları. Arşiv, 16, 145-159.

Renkielska A, Nowakowski A, Kaczmarek M, et al. (2005). Static thermography revisited-An adjunct method for determining the depth of the burn injury. Burns, 31, 768-775.

Renkielska A, Nowakowski A, Kaczmarek M, Ruminski J (2006). Burn depths evaluation based on active dynamic IR thermal imaging-A preliminary study. Burns, 32, 867-875.

Ring EF, Ammer K (2012). Infrared thermal imaging in medicine. Physiol Meas, 33, 33-46.

Sclafani AP (2010). Platelet-rich fibrin matrix for improvement of deep nasolabial folds. J Cosmet Dermatol, 9, 66-71.

Subrahmanyam M (1998). A prospective randomised clinical and histological study of superficial burn wound healing with honey and silver sulfadiazine. Burns, 24, 157-161.

Weibrich G, Kleis WKG, Kunz-Kostomanolakis M, loos AH, Wagner W (2001). Correlation of platelet concentration in platelet-rich plasma to the extraction method, age, sex, and platelet count of the donor. J Oral Maxillofac Surg, 16 (5), 693-699.

Yüksel EB (2012). Rat Yanık Yarasında Gümüş Sülfadiazin, Povidon İyot ve İzotonik Sodyum Klorür Etkisinin Araștırılması, Uzmanlık Tezi, Fırat Üniversitesi Tıp Fakültesi, Elazı̆̆. 